\title{
George Sand, La Petite Fadette
}

\section{Lise Sabourin}

\section{(2) OpenEdition}

\section{Journals}

Édition électronique

URL : http://journals.openedition.org/studifrancesi/34911

DOI : 10.4000/studifrancesi.34911

ISSN : 2427-5856

Éditeur

Rosenberg \& Sellier

\section{Édition imprimée}

Date de publication : 1 novembre 2005

Pagination : 432

ISSN : 0039-2944

\section{Référence électronique}

Lise Sabourin, «George Sand, La Petite Fadette», Studi Francesi [En ligne], 146 (XLIX | II) | 2005, mis en ligne le 30 novembre 2015, consulté le 20 avril 2021. URL : http://journals.openedition.org/ studifrancesi/34911 ; DOI : https://doi.org/10.4000/studifrancesi.34911

\section{Ce document a été généré automatiquement le 20 avril 2021.}

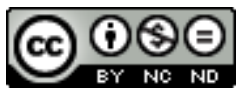

Studi Francesi è distribuita con Licenza Creative Commons Attribuzione - Non commerciale - Non opere derivate 4.0 Internazionale. 


\title{
George Sand, La Petite Fadette
}

\author{
Lise Sabourin
}

\section{RÉFÉRENCE}

GEORGE SAND, La Petite Fadette, édition par MARTINE REID, Paris, Gallimard, 2004

(«Folioclassique»), pp. 281.

1 Martine Reid présente et annote le dernier roman de la trilogie champêtre (après $L a$ Mare au Diable et François le champi) qui aurait dû s'insérer dans Les Veillées d'un chanvreur projetées par Sand. Sa préface montre la subtile fusion de la bergerie traditionnelle (dans la ligne de l'Essai sur la pastorale de Florian en 1787) et du conte moral (telles Les Veillées du château de Mme de Genlis que sa grand-mère lisait à la future romancière). Mais, après la double déception politique de 1848 - auto-protection de la bourgeoisie et imprépamtion du peuple - George Sand conjugue aussi son rêve humanitaire à une observation quasi ethnographique des paysans de sa chère Vallée noire, en une commutativité évidente avec ses souvenirs d'enfance simultanément narrés comme par effet de miroir dans Histoire de ma vie. Tout en procédant à une «fixation muséale» (p. 24) du Berry du début de son siècle, elle exprime son désir de «poétiser la vie» par un travail esthétique très fin sur les croyances régionales et le parler paysan dont elle se fait l'antiquaire. Le dossier éditorial fournit, outre la préface de l'édition originale, une notice sur la langue sandienne, accompagnée d'un glossaire des mots berrichons, qui permet de mieux mesurer la force littéraire de cette narration maîtrisée, qu'on a trop longtemps restreinte à une lecture illustrée ou adaptée pour la jeunesse. 